\title{
PENGGUNAAN STRATEGI THINK-TALK-WRITE (TTW) DENGAN MODEL PROBLEM BASED LEARNING UNTUK MENINGKATKAN AKTIVITAS DAN HASIL BELAJAR BAHASA INDONESIA PADA PESERTA DIDIK KELAS XI MIPA 1 SEMESTER 1 SMA N 1 KUTA UTARA TAHUN PELAJARAN 2019-2020
}

\author{
I Wayan Putra \\ SMA N 1 KUTA UTARA
}

\begin{abstract}
Abstrak
Penelitian ini bertujuan (1) untuk mendeskripsikan berhasil atau tidaknya penggunaan Strategi ThinkTalk-Write (TTW) Dengan Model Problem Based Learning yang efektif untuk meningkatkan aktivitas menulis teks editorial peserta didik Kelas XII MIPA 1 Semester Ganjil SMA N 1 Kuta Utara Tahun Pelajaran 2019-2020. (2) Untuk mendeskripsikan berhasil atau tidaknya penggunaan Strategi Think-Talk-Write (TTW) Dengan Model Problem Based Learning yang efektif untuk meningkatkan hasil belajar menulis teks editorial peserta didik Kelas XII MIPA 1 Semester Ganjil SMA N 1 Kuta Utara Tahun Pelajaran 2019-2020. Pengumpulan data dilakukan dengan tes, observasi, wawancara dan angket (kuisioner). Data yang diperoleh dianalisis secara deskriftif kualitatif dan deskrifitif kuantitatif. Hasil penelitian ini menunjukkan bahwa Strategi Think-Talk-Write (TTW) dengan Model Problem Based Learning dapat meningkatkan kemampuan menulis teks editorial. Peningkatan ini dapat diketahui dari peningkatan skor siswa. Skor tes pratindakan hanya mencapai 61,20 . Setelah diadakannya siklus I skor rata-rata 62,92 dan pada siklus II skor rata-rata 84,86. Peningkatan ini terjadi karena langkah-langkah yang digunakan dalam kegiatan menulis teks editorial menggunakan Strategi Think-Talk-Write (TTW) dengan Model Problem Based Learning sangat tepat. Siswa kelas XII MIPA 1 memberikan respon yang positif terhadap penggunaan Strategi Think-Talk-Write (TTW) dengan Model Problem Based Learning untuk meningkatkan kemampuan menulis teks editorial.

Kata kunci: strategi Think-Talk-Write (TTW), model Problem Based Learning, editorial
\end{abstract}

\begin{abstract}
This study aimed (1) to describe the success or failure of using the Think-Talk-Write (TTW) Strategy with an effective Problem Based Learning Model to increase the activity of writing editorial texts for students of Class XII MIPA 1 Odd Semester SMA N 1 North Kuta Academic Year 2019-2020. (2) to describe the success or failure of using the Think-Talk-Write (TTW) Strategy with an effective Problem Based Learning Model to improve learning outcomes in writing editorial text for students in Class XII MIPA 1 Odd Semester SMA N 1 North Kuta Academic Year 2019-2020. Data collection was carried out by means of tests, observations, interviews and questionnaires (questionnaires). The data obtained were analyzed descriptively qualitatively and descriptively quantitatively. The results of this study indicated that the Think-Talk-Write (TTW) Strategy with the Problem Based Learning Model improved the ability to write editorial texts. This increase saw from the increase in student scores. The pre-action test score only reached 61.20 . After holding cycle I the average score is 62.92 and in cycle II the average score is 84.86 . This increase occurred because the steps used in writing editorial text using the Think-Talk-Write (TTW) Strategy with the Problem Based Learning Model were very precise. Class XII MIPA 1 students gave a positive response to the use of the Think-Talk-Write (TTW) Strategy with the Problem Based Learning Model to improve their ability to write editorial texts.

Keywords: Think-Talk-Write (TTW) strategy, Problem Based Learning model, editorial
\end{abstract}

\section{Pendahuluan}

Kegiatan berbahasa pada dasarnya merupakan kegiatan berkomunikasi. Manusia sudah menggunakan bahasa sebagai alat komunikasi antar sesamanya sejak berabad-abad silam. Pada intinya bahasa adalah tanda dan simbol yang mewakili sesuatu yang diungkapkan, baik lisan maupun tulisan (Swarniti \& Yuniari, 2019). Bahasa hadir sejalan dengan sejarah sosial komunitaskomunitas masyarakat atau bangsa. Pemahaman bahasa sebagai fungsi sosial menjadi hal pokok manusia untuk 
mengadakan interaksi sosial dengan sesamanya (Adnyana dkk.2018:40). Oleh karena itu, belajar bahasa pada hakikatnya sama dengan belajar berkomunikasi. Kegiatan berkomunikasi dengan bahasa terwujud dalam empat aspek keterampilan, yaitu keterampilan menyimak, berbicara, membaca, dan menulis. Salah satu keterampilan berbahasa yang penting diajarkan dan ditingkatkan pada siswa adalah keterampilan menulis. Tujuan pembelajaran keterampilan menulis adalah melatih siswa untuk dapat menuangkan pikirannya dalam bentuk komunikasi secara tertulis sebagai komunikasi secara tidak langsung. Menulis merupakan suatu kegiatan yang produktif dan ekspresif dalam melatih keterampilan dengan memanfaatkan grafologi, struktur bahasa, dan kosakata. Keterampilan ini tidak akan datang secara otomatis melainkan harus melalui proses latihan dan praktik secara teratur. Akhadiah (1988: 2) mengungkapkan bahwa menulis merupakan kemampuan kompleks, yang menuntut sejumlah pengetahuan dan keterampilan. Menulis karangan yang sederhanapun, secara teknis dituntut memenuhi persyaratan dasar seperti menulis karangan yang rumit, yakni harus memilih topik, membatasinya, mengembangkan gagasan, enyajikannya dalam kalimat dan paragraf yang tersusun secara logis. Melalui latihan yang sungguh-sungguh kemampuan itu dapat dimiliki siapa saja.

Menulis bukan pekerjaan yang sekali jadi, tetapi memerlukan proses. Proses itu dimulai dari menemukan topik, memecahkan topik menjadi kerangka, dan mengembangkan kerangka menjadi sebuah karangan. Namun, menuangkan buah pikiran secara teratur dan teorganisasi ke dalam sebuah tulisan sehingga pembaca dapat memahami jalan pikiran seseorang tidaklah mudah. Morsey (dalam Tarigan, 2008: 20) mengatakan bahwa tulisan dipergunakan untuk merekam, meyakinkan, melaporkan, dan mempengaruhi orang lain, dan tujuan tersebut hanya tercapai dengan baik oleh para penulis yang dapat menyusun pikiranya serta mengutarakannya dengan jelas atau mudah dipahami; kejelasan tersebut tergantung pada pikiran, organisani, susunan, penggunaan kata-kata, dan setruktur kalimat.

Tujuan menulis adalah agar tulisan yang dibuat dapat dibaca dan dipahami oleh orang lain yang mempunyai kesamaan pengertian terhadap bahasa yang dipergunakan. Dapat dikatakan bahwa menulis merupakan salah satu cara berkomunikasi secara tertulis karena tidak semua orang dapat mengungkapkan perasaan dan pikiranya secara lisan saja. Dengan demikian, keterampilan menulis menjadi salah satu cara berkomunikasi kerena dalam pengertian tersebut muncul kesan adannya pengirim danpenerima pesan.

Menulis memerlukan adanya suatu bentuk ekspresi gagasan yang berkesinambungan dan mempunyai urutan logis dengan menggunakan kosakata tata bahasa tertentu atau kaidah bahasa yang dipergunakan sehingga menyajikan informasi yang diekspresikan secara jelas. Itulah sebabnya untuk terampil menulis diperlukan latihan teratur dan praktik yang terus-menerus.

Dalam pengajaran bahasa, keterampilan menulis merupakan salah satu cara untuk menyampaikan maksud dan tujuan dengan cara tertulis yang merupakan kemampuan siswa untuk mengekspresikan maksud melalui media bahasa. Untuk melakukan pekerjaan menulis sebelumnya 
diperlukan perencanaan yang matang mengenai topik yang akan ditulis, tujuan yang hendak disampaikan, dan pembahasan yang akan diuraikan. Semua itu dilakukan karena menulis merupakan proses berpikir. Kedalaman dan kejelasan berpikir meningkatkan mutu tulisan. Pada saat yang sama, menulis adalah sarana belajar untuk meningkatkan dan menyempurnakan gagasan. Berkaitan dengan penjelasan di atas, keterampilan menulis pun diajarkan sekolah menengah atas. Dalam kurikulum 2013 Bahasa Indonesia untuk SMA misalnya KD 4.6 Merancang teks editorial dengan memerhatikan struktur dan kebahasaan baik secara tulis maupun secara lisan. Betapa pentingnya peranan bahasa dalam tatapergaulan manusia karena bahasa merupakan sarana komunikasi paling utama bagi manusia. Melalui bahasa seorang dapat mengungkapkan segala isi pikiran, perasaan, gagasan, ide, dan pesan, baik dalam bentuk tertulis maupun lisan. Sebagai sarana komunikasi pembelajaran menulis diajarkan kepada para siswa melalui pendekatan tertentu yang sesuai dengan hakikat dan fungsinya. Pendekatan pembelajaran bahasa harus dengan pendekatan komunikatif yaitu pendekatan yang menekankan pada aspek kinerja dan kemahiran berbahasa.

Dengan demikian orang tidak akan berpikir tentang sistem bahasa melainkan berpikir bagaimana menggunakan bahasa secara benar sesuai dengan sistem itu. Pembelajaran berbahasa haruslah lebih menekankan fungsi bahasa sebagai alat komunikasi daripada pembelajaran tentang sistem bahasa. (Pedoman Khusus Pengembangan Silabus dan Penilaian, 2004: 2)
Keterampilan menulis tidak didapatkan secara alamiah, tetapi harus melalui proses belajar dan berlatih. Dengan penguasaan keterampilan menulis diharapkan siswa dapat mengungkapkan gagasan, pikiran, dan perasaan yang dimiliknya setelah menjalani proses pembelajaran dalam berbagai jenis tulisan, baik fiksi maupaun nonfiksi.

Keterampilan menulis telah diajarkan diberbagai jenjang pendidikan dari Sekolah Dasar hingga Perguruan Tinggi. Meskipun demikian, pembelajaran menulis telah lama menjadi masalah dalam sistem pembelajaran bahasa Indonesia. Tidak dapat dipungkiri, bahwa sampai saat ini masih banyak terjadi sistem pembelajaran yang kurang sesuai. Kekurangtepatan tidak tercapainya tujuan pembelajaran terutama pembelajaran menulis.

Berdasarkan pengamatan dan wawancara Kompetensi Dasar Teks Opini/Editorial khususnya pada memproduksi teks opini/editorial pada siswa kelas X11 MIPA 1 SMA Negeri 1 Kuta Utara diperoleh data bahwa minat dan kemampuan siswa kelas X11 MIPA 1 Kuta Utara. dalam memproduksi teka opini/editorial belum memuaskan.

Berdasarkan latar belakang di atas maka penulis ingin melakukan penelitian tindakan kelas dengan judul "Penggunaan Strategi Think-TalkWrite (TTW) dengan Model Problem Based Learning untuk Meningkatkan Aktivitas dan Hasil Belajar Bahasa Indonesia Pada Pada Peseta Didik Kelas XII MIPA 1 Semester 1 SMA N 1 Kuta Utara Tahun Pelajaran 2019-2020”

Adapun permasalahan yang diangkat dari latar belakang diatas adalah apakah dengan 
menggunakan Strategi Think-Talk-Write (TTW) dengan Model Poblim Based Learning mampu meningkatkan aktivitas menulis teks editorial peserta didik Kelas XII MIPA 1 Semester ganjil SMA N 1 Kuta Utara Tahun Pelajaran 2019-2020?” Apakah menggunakan Strategi Think-Talk-Write (TTW) dengan Model Problim Based Learning mampu meningkatkan hasil belajar menulis teks editorial peserta didik Kelas XII MIPA 1 Semester ganjil SMA N 1 Kuta Utara Tahun Pelajaran 20192020?" Ini bertujuan untuk menemukan celah, kekuatan, dan kelemahan. Sangat membantu penelitian ini untuk mengisi kekosongan dan menjadi penelitian yang berbeda (Wayan Swarniti, 2019).

\section{Metode Penelitian}

Penelitian ini merupakan penelitian tindakan kelas (PTK), yakni penelitian yang berbasis kelas atau sekolah. Penelitian ini dilakukan dengan maksud untuk meningkatkan kemantapan rasional dari tindakan-tindakan yang dilakukan. Siklus ini terdiri dari empat komponen yaitu: perencanaan, tindakan, observasi, dan refleksi (Tripp dalam Subyantoro 2009:17). Keempat komponen itu dipandang sebagai satu siklus. Jika siklus I nilai rata-rata belum mencapai target yang telah ditentukan, maka dilakukan tindakan siklus II.

Penelitian berlangsung di kelas XII MIPA 1 SMA Negeri 1 Kuta Utara yang terletak di Jalan I Made Bulet No.19 Kuta Utara, Kabupaten Badung, Provinsi Bali. SMA Negeri 1 Kuta Utara Terletak di Desa Dalung. Sedangkan waktu penelitian diadakan pada semester 1 (Ganjil) tahun ajaran 2019/2020. Penelitian dilaksanakan selama 6 bulan dari bulan Juli 2019 sampai dengan bulan Desember 2019.

Subjek penelitian ini adalah siswa kelas XII MIPA 1 tahun pelajaran 2019/2020 yang berada di SMA Negeri 1 Kuta Utara, Kabupaten Badung.Jumlah subjek penelitian 38 siswa yang terdiri dari 17 siswa putra dan 21 siswa putri. Kondisi kemampuan dalam memproduksiteks opin/editorial masih kurang karena hasil ulangan harian pada pra siklus hanya mencapai rata-rata 60 .

Siswa kelas XII MIPA 1 sebagai subjek penelitian ini memiliki karakteristik yang heterogen. Heterogen baik dalam segi kecakapan intelegensi, motivasi belajar, latar belakang keluarga, maupun sifat dan wataknya. Dari segi watak ada beberapa siswa yang memiliki watak sulit diatur, pembelajaran berlangsung.Mereka juga berasal dari latar belakang keluarga yang berbeda. Namun secara umum siswa memiliki kepribadian yang baik.

Penelitian ini menggunakan rancangan Penelitian Tindakan Kelas (PTK) yang terdiri dari 2 siklus.Tiap siklus dilaksanakan dalam empat tahap meliputi (a) tahap perencanaan (b) tahap tindakan (c) tahap pengamatan (d) tahap refleksi.Siklus I dilaksanakan untuk mengetahui kemampuan memproduksi teks opini/editorial.Tahapan pelaksanaan tindakan siklus dapat dijelaskan sebagai berikut, tahap perencanaan yaitu dengan menyusun RPP, menyiapkan lembar penilaian,lembar observasi, pedoman wawancara.Tahap pelaksanaan dengan menerapkan strategi pembelajaran TTWyang meliputi tiga kegiatan yaitu siswa membaca teks dan membuat catatan dari hasil bacaan secara individual, untuk dibawa ke forum diskusi (Think), 
siswa berinteraksi dan berkolaborasi dengan teman untuk membahas isi catatan (Talk), dan siswa mengkonstruksi sendiri pengetahuan sebagai hasil kolaborasi (write).
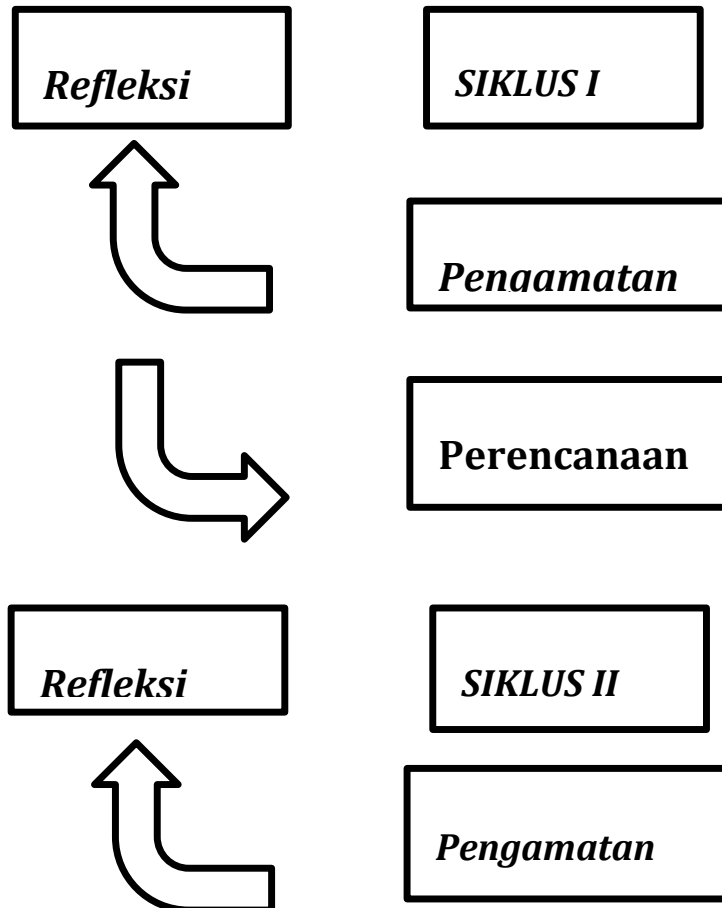

\section{Perencanaan}
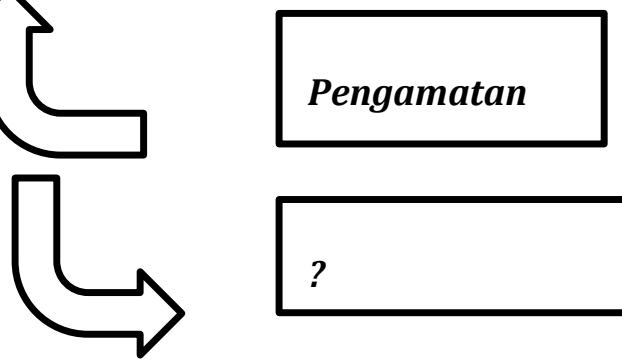$$
?
$$

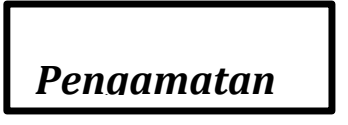

Penelitian Tindakan Kelas sebagaimana dinyatakan oleh Arikunto (2010:117) merupakan penelitian yang bersiklus, terdiri dari rencana, aksi, observasi, dan refleksi yang dilakukan secara berulang, diagramnya sebagai berikut:

\section{Pelaksanaan}
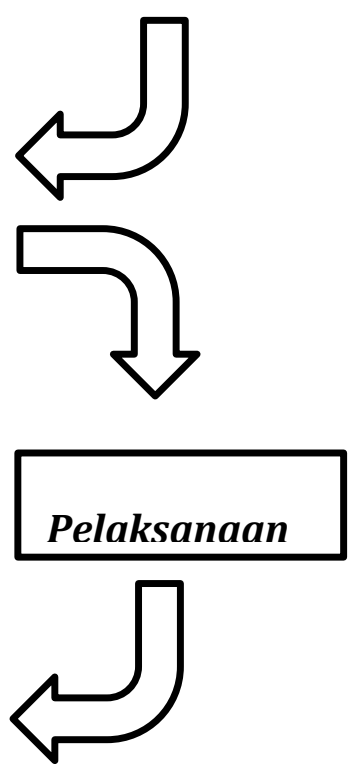

\section{HASIL DAN PEMBAHASAN}

Untuk lebih memahami tentang menulis editorial maka guru memberikan tes tentang menulis editorial dengan memberikan beberapa tema. Tulisan teks editorial dibuat sesuai dengan kriteria penulisan tekseditorial yang sudah ditentukan. Hasil akhir dari penulisan tekseditorial silus I dapat dilihat pada grafik berikut ini. 


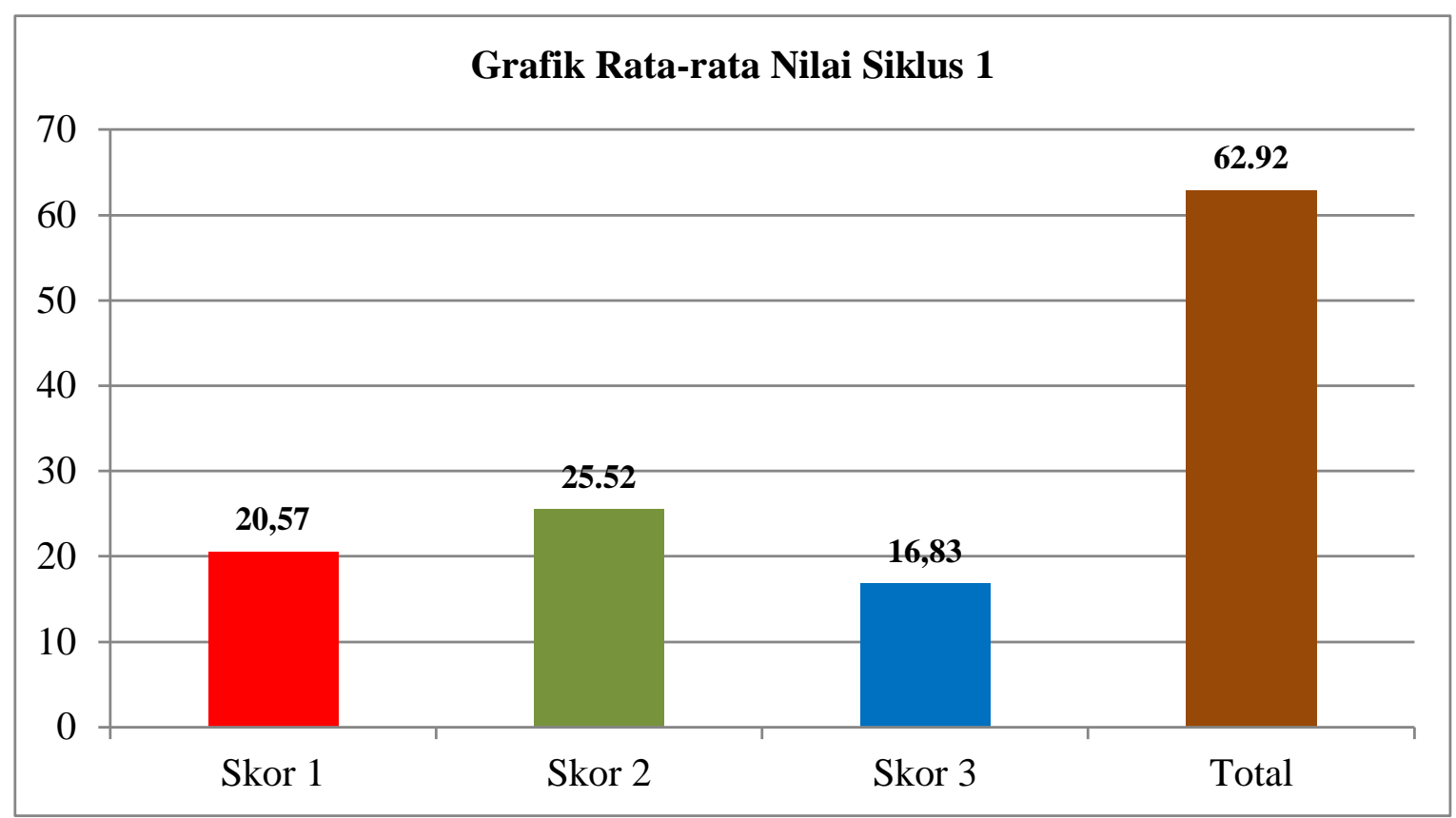

Keterangan:

1. Pengenalan isu (skor 1 )

2. Penyampaian pendapat/argumen (skor 2)

3. Penegasan (skor 3)

Hasil evaluasi terhadap keterampilan menulis editorial pada grafik di atas memperlihatkan bahwa skor satu tentang pengenalan isu siswa baru menguasai 20,57\% dari skor maksimal 25,00, penyampaian pendapat/argumen $25,52 \%$ dari skor maksimal $50,00 \%$ dan penegasan $16,83 \%$ dari skor maksimal 25,00\% kemudian skor total $62,92 \%$. Skor tersebut belum mencerminkan keberhasilan secara klasikal yaitu $85 \%$ dengan demikian penelitian harus dilakukan kembali Melalui siklus II.

Grafik 2 Rata-rata Nilai Siklus 2 


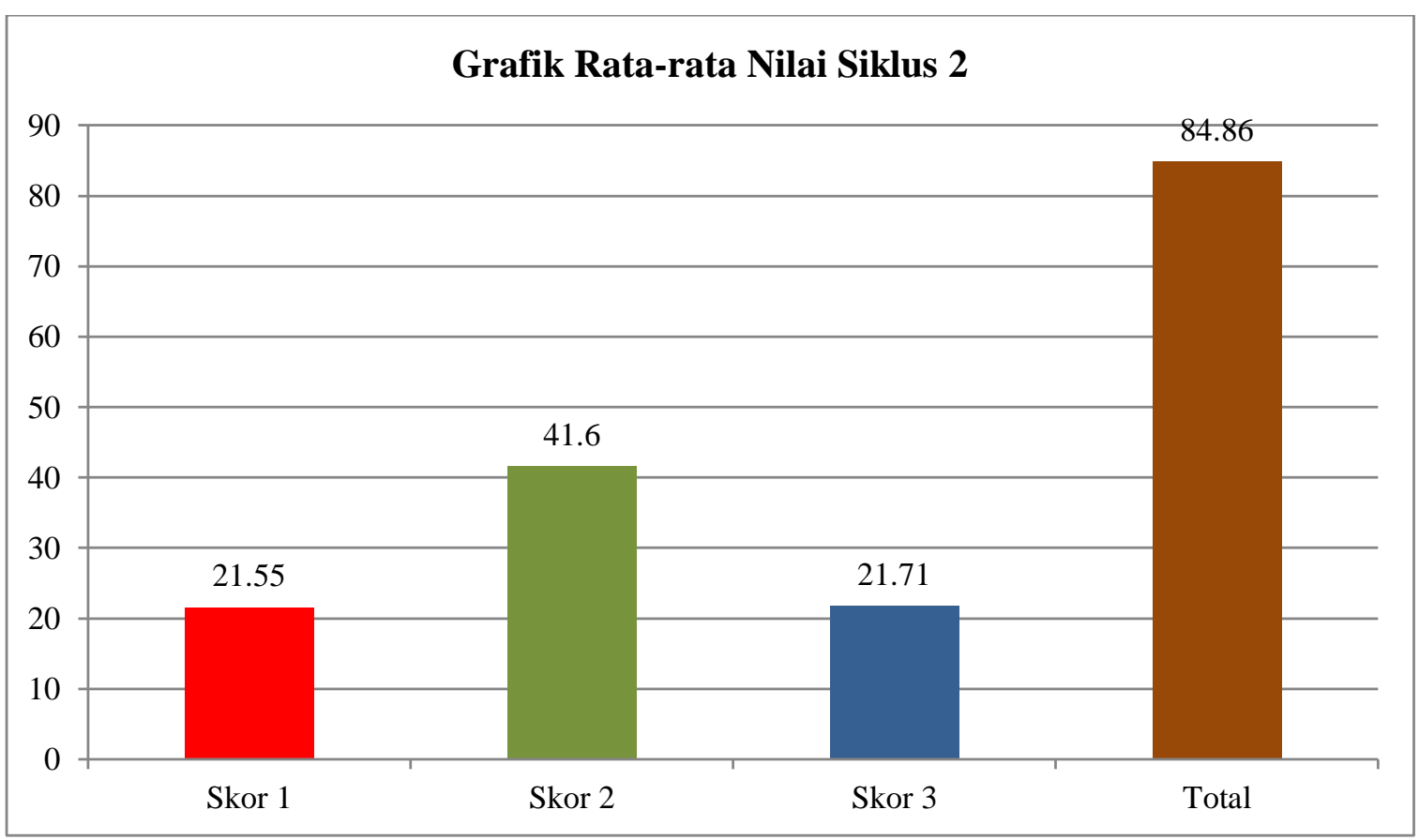

Keterangan:

1. Pengenalan isu (skor 1 )

2. Penyampaian pendapat/argumen (skor 2)

3. Penegasan (skor 3)

Hasil evaluasi terhadap keterampilan menulis editorial pada grafik di atas memperlihatkan maksimal 50,00\% dan penegasan $21,71 \%$ dari skor bahwa skor satu tentang pengenalan isu siswa baru menguasai $21,55 \%$ dari skor maksimal 25,00, penyampaian pendapat/argumen $41,06 \%$ dari skor maksimal $25,00 \%$ kemudian skor total $84,86 \%$. Skor tersebut belum mencerminkan keberhasilan secara klasikal yaitu $85 \%$ dengan demikian penelitian sudah dikatakan berhasil 


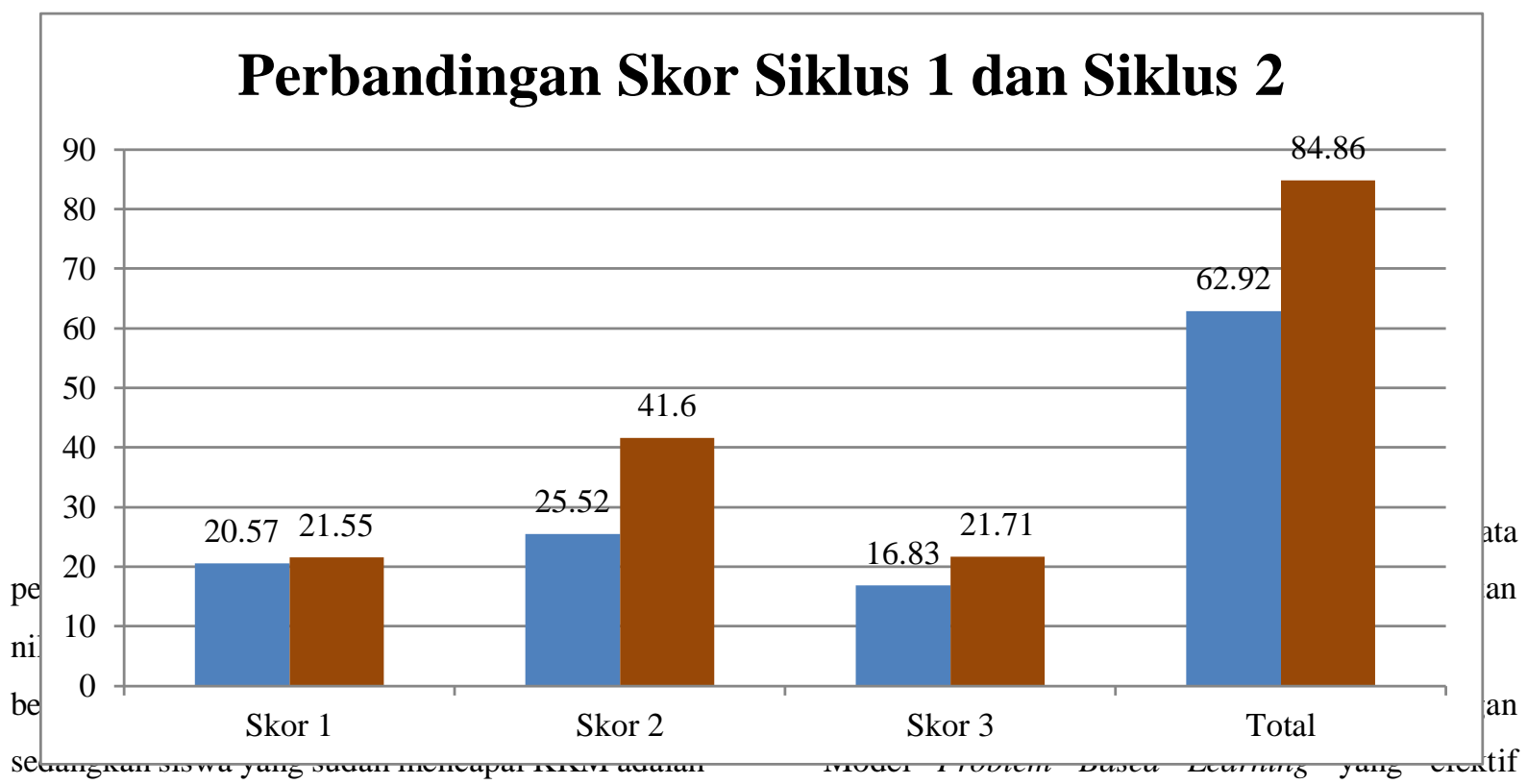

11 orang atau $(28,94 \%)$ dimana KKM yang harus dicapai 65. Untuk siklus II Berdasarkan tabel dan grafik di atas, satu orang siswa $(2,63 \%)$ masih memperoleh nilai dibawah KKM 65 dan sebanyak 37 orang $(97,36 \%)$ sudah mencapai nilai diatas KKM. Penelitian ini dikatakan berhasil, jika $85 \%$ siswa memperoleh skor sama atau lebih besar dari pada $65 \%$. Pada siklus II terjadi peningkatan skor rata-rata dari 62,92 pada siklus I menjadi 84,86 pada siklus II. Jadi peningkatan yang terjadi sebesar $21,94 \%$. Dengan demikian tindakan tersebut dapat dikatakan berhasil.

\section{Penutup}

Berdasarkan uraian pada bab IV, dalam penelitian ini dapat ditarik beberapa simpulan berikut.

Strategi Think-Talk-Write (TTW) Dengan Model Problem Based Learning yang efektif mampu meningkatkan aktivitas menulis teks editorial. aktivitas siswa pada siklus I memperoleh mampu meningkatkan hasil belajar khususnya meningkatkan keterampilan menulis teks editorial pada siswa kelas XII MIPA 1 yang ditandai dengan peningkatan skor pengenalan isu 0,98 , peningkatan skor argumentasi 16,08, peningkatan skor penegasan ulang 4,88. Skor nilai rata-rata siklus I adalah 62,92 menjadi 84,86 pada siklus II, terjadi peningkatan rata-rata sebesar 21,94

\section{DAFTAR RUJUKAN}

Abidin, Yunus, (2015) Pembelajaran Multiliterasi. Bandung: Refika Aditama

Adnyana, I Ketut Suar, Made Suwendi, Dayu Novita Yogan Dewi. (2018). "Dominasi Laki-laki pada Masyarakat Matrilineal Suku Tetun, Kabupaten Malaka, Nusa Tenggara Timur Berdasar pada Penggunaan Bahasa”. Prosiding Seminar Nasional Menggali Pengalaman Pembelajaran Bahasa dan Sastra Indonesia di Sekolah. Program Studi Pendidikan Bahasa dan Sastra Indonesia. Universitas Pendidikan Ganesha. Singaraja 20-21September 2018. Halaman 40- 50. 
Akhadiah, Sabarti (1997) Menulis I, Jakarta: Universitas Indonesia

Anas, Sudijono.1995. Pengantar Evaluasi Pendidikan. Rajawali Pers. Jakarta.

Arikunto, Suharsimi. 2010. Penelitian Tindakan Kelas. Yogyakarta, Aditya Media

Aris, Shoimin. 2014. 68 Model Pembelajaran Inovatif dalam Kurikulum 2013. Yogyakarta : Ar-Ruzz Media

Depdiknas RI.2006.Standar Kompetensi Indonesia. Jakarta: Bumi Aksara.

Fauzi, Emi. (2017). Peningkatan Kemampuan Memproduksi Teks Opini/Editorial Melalui Penggunaan Strategi Think- Talk-Write (TTW) Dengan Model Project-BasedLearning Pada Peserta Didik Kelas XII MIPA 3 Semester 2, SMA N 1 Paguyangan, Brebes, Tahun Pelajaran 2016/2017

Kamdi. 2007. Strategi Pembelajaran. Bandung:PT Remaja Rosdakarya

Kementerian Pendidikan danKebudayaan.2015. Bahasa Indonesia Ekspresi Diri dan

Akademik. Jakarta: Pusat Kurikulum dan Pembukuan, Balitbang Kemdikbud.

Kementerian Pendidikan dan Kebudayaan.2015. Materi pelatihan Guru Implementasi Kurikulum 2013 Tahun Ajaran 2014/2015.

Kementerian Pendidikan dan Kebudayaan.2018. Bahasa Indonesia.Bandung, Pusat Kurikulum dan Pembukuan, Balitbang Kemdikbud

Kosasih, E. (2014). Jenis-Jenis Teks Analisis Fungsi, Struktur, dan Kaidah serta Langkah Penulisannya dalam Mata Pelajaran Bahasa Indonesia SMA/MA/SMK. Bandung: Yrama Wiidya.

Mulyadi,Hadi, 2017. Buku teks pendamping Bahasa Indonesia untuk SMA- MA/SMKMAK Kelas XII. Bandung: Yrama Widya.
Mulyoto. 2006. Kiat Menulis untuk Media Massa. Klaten: Sahabat.

Sabariyanto, Dirgo. 1999. Mengapa Disebut Bentuk Baku dan Tidak Baku? Jakarta: Mitra Gama Widya.

Santika, I Gusti Ngurah. 2017. Kepala Sekolah Dalam Konsep Kepemimpinan Pendidikan: Suatu Kajian Teoritis. Widya Accarya. 7 (1).

Santika, I. G. N., Rindawan, I. K., \& Sujana, I. G. (2019). Memperkuat Pancasila Melalui Pergub No. 79 Tahun 2018 Dalam Menanggulangi Pengikisan Budaya Di Era Revolusi Industri 4.0. Prosiding Seminar Nasional Inobali 2019, 79, 981-990

Subyantoro. 2009. Penelitian Tindakan Kelas. Semarang: Rumah Indonesia.

Subyantoro. 2017. PTK (Penelitian Tindakan Kelas). Semarang: Fanishma Indonesia.

Suherli. 2008. Menulis Karangan Ilmiah. Depok: Arya Duta.

Swarniti, N. W., \& Yuniari, N. M. (2019). Keberadaan Leksikon Pohon Langka di Denpasar: Studi Ekolinguistik. Seminar Nasional INOBALI 2019 Inovasi Baru Dalam Penelitian Sains, Teknologi Dan Humaniora, 405-411.

https://eproceeding.undwi.ac.id/index.php/ino bali/article/view/180

Wayan Swarniti, N. (2019). The Translation Procedures of Bible Translation. 5(2), 187196. https://doi.org/10.22225/jr.5.2.1277.187196

Tarigan Henry Guntur. 2008. Menulis sebagai Suatu Keterampilan Berbahasa. Bandung: Angkasa.

www.infoduniapendidikan.com/2015/06/pengertia n-dan-langkah-model- pembelajaranproblem-based-learning.html?m=1 diunduh pada tanggal 17 Juli 2019 